\title{
PENETAPAN STRATEGI PEMASARAN BERDASARKAN ANALISIS SWOT PADA WHEELS AND BRAKES CAFÉ SURABAYA
}

\author{
${ }^{*}$ Wartalena Irene Halawa ${ }^{1}$ \& ${ }^{*}$ Thyophoida W. S. Panjaitan ${ }^{2}$ \\ ${ }^{1,2}$ Departemen Manajemen, Fakultas Ekonomi, Universitas Katolik Darma Cendika, Surabaya \\ *)thyophoida.panjaitan@ukdc.ac.id
}

\begin{tabular}{l}
\hline Informasi Artikel \\
\hline Draft awal: 29 Juli 2021 \\
Revisi : 3 Agustus 2021 \\
Diterima : 20 Agustus 2021 \\
Available online: 29 September \\
2021 \\
\hline
\end{tabular}

Keywords: SWOT, Entrepreneur, Cafe, Opportunity, Position, Strategy

Tipe Artikel : Research paper

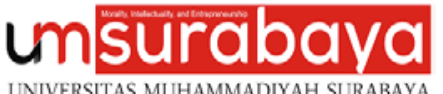

Diterbitkan oleh Universitas Muhammadiyah Surabaya

\section{ABSTRACT}

Wheels and Brakes Café is one of the cafes in Surabaya in January 2017. The evaluation process will certainly help in achieving Cafe Owners' desire to increase Cafe's income. One of the tools that can be used to conduct the evaluation is SWOT Analysis (Strength, Weakness, Opportunities, Threats).

Informants in this study were Cafe Managers, Cafe Employees, and Key Consumers. In this study also used other tools besides SWOT Matrix, namely SPACE Matrix, IFAS Matrix, EFAS Matrix, and IE Matrix. The SPACE matrix has $x, y$ coordinates $(1.5 ;-0.5)$ which indicate that the Cafe is in quadrant III with a Competitive Strategy. In IFAS Matrix, the total internal factor value is 2.77 while the EFAS Matrix has a total external factor value of 3.05. After combining the IFAS and EFAS values, in the IE Matrix it was found that Wheels and Brakes Café Surabaya was in position II which indicated that the position of the Cafe was in growing conditions and Horizontal Integration strategy suggestions.

The results of this study indicate that the right strategy to use Wheels and Brakes Café Surabaya is the Horizontal Integration Strategy. This strategy takes into account market penetration, market development, and product renewal. This strategy is certainly right for Wheels and Brakes Café Surabaya to be more competitive in the restaurant and cafe business.

Wheels and Brakes Café merupakan salah satu Kafe di Surabaya pada Januari 2017. Proses evaluasi yang dilakukan tentu akan membantu dalam mencapai keinginan Pemilik Kafe dalam meningkatkan pendapatan Kafe. Salah satu alat yang bisa digunakan untuk melakukan evaluasi tersebut ialah Analisis SWOT (Strength, Weakness, Opportunities, Threats).

Informan dalam penelitian ini ialah Manajer Kafe, Karyawan Kafe, dan Konsumen Kunci. Dalam penelitian ini juga digunakan alat bantu lain selain Matrik SWOT yaitu Matrik SPACE, Matrik IFAS, Matrik EFAS, dan Matrik IE. Matrik SPACE didapatkan koordinat x,y $(1,5 ;-0,5)$ yang menunjukkan bahwa Kafe berada di kuadran III dengan Strategi Kompetitif. Pada Matrik IFAS didapatkan nilai total faktor internal sebesar 2,77 sedangkan pada Matrik EFAS total nilai faktor eksternal sebesar 3,05. Setelah menggabungkan antara nilai IFAS dan EFAS, pada Matrik IE didapatkan bahwa Wheels and Brakes Café Surabaya berada di posisi II yang menunjukkan bahwa posisi Kafe dalam kondisi bertumbuh dan saran strategi Integrasi Horizontal.

Hasil penelitian ini menunjukkan bahwa Strategi yang tepat untuk digunakan Wheels and Brakes Café Surabaya ialah Strategi Integrasi Horizontal. Strategi ini memperhatikan Penetrasi pasar, Pengembangan Pasar, dan Pembaharuan Produk. Strategi ini tentunya tepat bagi Wheels and Brakes Café Surabaya untuk lebih kompetitif dalam bisnis Restoran dan Kafe. 


\section{PENDAHULUAN}

Masyarakat Surabaya memiliki hobi melakukan wisata kuliner (Manai, 2015). HAl tersebut didukung pernyataan Ketua Asosiasi Pengusaha Kafe dan Restoran Indonesia (Apkrindo) Jawa Timur, yang menjelaskan demand masyarakat terhadap kuliner selalu ada. Tingginya minat masyarakat pada kuliner menjadi faktor penting dalam mendorong pemain bisnis kuliner dalam berinvestasi di industri makanan dan minuman (Car, 2018). Kondisi tersebut sangat memungkinkan bagi bisnis food and beverages untuk berkembang serta dilirik para entrepreneur untuk berkecimpung pada bisnis Kafe dan Restoran (Fatihudin, et al., 2019).

Ketua Apkrindo Jatim menyatakan pertumbuhan industri Kafe atau Restoran di Surabaya sangat subur diakibatkan adanya perkembangan ekonomi makro (Sofyan, 2015), serta dipicu perubahan gaya hidup masyarakat yang memiliki kegemaran mengunjungi Restoran dan Kafe guna berkumpul dengan teman atau keluarga (Ravikawati, et al., 2019). Tetapi pada realitanya, bisnis Food and Beverages di Surabaya tidak memberikan pendapatan yang meningkat secara konsisten. Oleh karena itu, para entrepreneur perlu menggunakan strategi yang tepat (Kotler, 2007). Dengan menggunakan strategi yang tepat dalam menjalankan usahanya pendapatan para pengusaha akan meeningkat (Hidayatullah, 2019).

Wheels and Brakes Café merupakan salah satu bisnis food and beverages yang berdiri berdasarkan peluang besar pada bisnis tersebut. Kafe ini memiliki konsep Paddock Tim Formula Satu serta memiliki desain interior yang bagus, unik dan Instagramable yang mana menjadi salah satu keunggulan yang dimiliki (Hardhiyana, Surya. 22 November 2017).

Proses evaluasi akan membantu dalam mencapai keinginan Enterpreneur untuk memperbaiki kondisi perusahaan (Afandi, 2014). Salah satu alat yang bisa digunakan untuk melakukan evaluasi tersebut ialah menganalisis Strength, Weakness, Opportunities, Threats atau yang sering disebut dengan SWOT (Srinandi, 2016). SWOT dilakukan untuk dapat menetapkan strategi pemasaran (Fahmi, 2014) yang tepat untuk dapat meningkatkan pendapatan yang akan diperoleh Wheels and Brakes Café.

Adapun tujuan dari penelitian ini adalah untuk menetapkan strategi pemasaran bagi Wheels and Brakes Café Surabaya berdasarkan hasil Analisis SWOT.

\section{LANDASAN TEORI}

\section{Restoran}

Restoran berasal dari kata rest yang memiliki arti tempat untuk beristirahat dan taurant yang memiliki arti bangunan permanen (Car, 2018). Apabila kedua kata ini digabungkan dapat menjadi tempat untuk beristirahat pada sebuah bangunan yang dibuat secara permanen (Riyadi, 2015:5), kegiatan-kegiatan di Restoran berfokus kepada food (makanan), beverage (minuman) dan service (pelayanan) maka dapat dikaitkan secara langsung yakni dalam memulihkan stamina ataupun beristirahat dengan menikmati makanan dan minuman serta pelayanannya.

\section{SWOT}

SWOT dijadikan sebagai suatu model dalam menganalisis suatu organisasi yang berorientasi profit dan non profit (Mochklas \& Wibowo, 2018) dengan tujuan utama untuk mengetahui keadaan organisasi tersebut secara lebih komprehensif (Abdullah, 2014).

Analisis SWOT (SWOT Analysis) merupakan teknik historis yang terkenal dimana para manajer menciptakan gambaran umum secara cepat mengenai situasi strategis perusahaan. Analisis SWOT Pearce \& Robinson (2014:156) didasarkan pada asumsi bahwa strategi yang efektif diturunkan dari "kesesuaian” yang baik antara sumber daya internal perusahaan (kekuatan dan kelemahan) dengan situasi eksternalnya (peluang dan ancaman).

Menurut Rangkuti (2015:83) Alat yang digunakan untuk menyusun faktor - faktor startegis perusahaan adalah matriks SWOT. Matriks ini dapat menggambarkan secara jelas bagaimana peluang dan ancaman eksternal yang dihadapi perusahaan dapat disesuaikan dengan kekuatan dan kelemahan yang dimilikinya. Matriks ini dapat menghasilkan empat set kemungkinan alternatif startegis. 


\begin{tabular}{|c|c|c|}
\hline 4 & $\begin{array}{c}\text { STRENGTH (S) } \\
\text { Tentukan 5-10 } \\
\text { faktor kelemahan } \\
\text { internal }\end{array}$ & $\begin{array}{l}\text { WEAKNESSES (w) } \\
\text { Tentukan 5-10 } \\
\text { kekuatan internal }\end{array}$ \\
\hline $\begin{array}{l}\text { OPPORTUNITIES (O) } \\
\text { Tentukan 5-10 } \\
\text { faktor peluang } \\
\text { eksternal }\end{array}$ & $\begin{array}{c}\text { STRATEGI SO: } \\
\text { Ciptakan strategi } \\
\text { yang menggunakan } \\
\text { kekuatan untuk } \\
\text { memanfaatkan } \\
\text { peluang. }\end{array}$ & $\begin{array}{c}\text { STRATEGI WO: } \\
\text { Ciptakan strategi } \\
\text { yang meminimalkan } \\
\text { kelemahan untuk } \\
\text { memanfaatkan } \\
\text { peluang. }\end{array}$ \\
\hline $\begin{array}{l}\text { THREATHS (T) } \\
\text { Tentukan 5-10 } \\
\text { faktorancaman } \\
\text { eksternal }\end{array}$ & $\begin{array}{c}\text { STRATEGIST: } \\
\text { Ciptakan strategi } \\
\text { yang menggunakan } \\
\text { kekuatan untuk } \\
\text { mengatasi } \\
\text { ancaman }\end{array}$ & $\begin{array}{c}\text { STRATEGI WT: } \\
\text { Ciptakan strategi } \\
\text { yang meminimalkan } \\
\text { kelemahan dan } \\
\text { menghindari } \\
\text { ancaman. }\end{array}$ \\
\hline
\end{tabular}

\section{Gambar 1. Matriks SWOT}

Sumber: Rangkuti, 2015:83)

\section{Analisis Swot}

Analisis SWOT adalah teknik historis dimana para manajer menciptakan gambaran umum secara cepat mengenai situasi strategis perusahaan. Analisis ini didasarkan pada asumsi bahwa strategi yang efektif diturunkan dari "kesesuaian" yang baik antara sumber daya internal perusahaan dengan situasi eksternalnya (Pearce \& Robinson, 2014:156)

\section{METODE PENELITIAN}

Penelitian ini merupakan penelitian kualitatif dan pendekatan yang dilakukan adalah deskriptif (Sugiyono. 2017). Penelitian ini berusaha untuk mengetahui kekuatan, kelemahan, peluang, dan ancaman pada Wheels and Brakes Café Surabaya sehingga akan menghasilkan strategi pemasaran yang sesuai untuk diterapkan pada Kafe. Pada penelitian ini, diambil 3 informan yaitu Manajer Wheels and Brakes Café Surabaya, Karyawan, dan Konsumen. Informan diwawancarai secara mendalam guna memperoleh informasi sebanyak-banyaknya tentang Wheels and Brakes Café. Penentuan bobot dan rating dari pernyataan diberikan oleh Manajer Kafe sebagai informan kunci pada penelitian ini.

Tehnik analisis data menggunakan serangkaian tahapan-tahapan sebagai berikut:

1. Matriks Kekuatan-Kelemahan-PeluangAncaman (SWOT).

Improvement: Jurnal Manajemen dan Bisnis Vol. 1 No. 2 September 2021
2. Matriks Posisi Strategis dan Evaluasi Tindakan (SPACE)

Matriks ini merupakan suatu alat yang digunakan untuk memetakan suatu kondisi menggunakan model diagram Cartesius

3. Matriks Internal Factors Analysis Strategies (IFAS)

Matrik IFAS (Internal Factors Analysis Strategy) pada penelitian ini digunakan untuk mengetahui nilai peran yang terdapat pada faktor-faktor internal di Wheels and Brakes Café Surabaya. Matriks ini menggambarkan kondisi internal pada kekuatan dan kelemahan yang dihitung berdasarkan rating dan bobot.

4. Matriks External Factors Analysis Strategies (EFAS)

Matrik EFAS (External Factors Analysis Strategies) ini digunakan untuk mengetahui nilai peranan dari faktorfaktor eksternal yang terdapat pada Wheels and Brakes Café Surabaya.

5. Matriks Internal-Eksternal (IE)

Merupakan perencanaan startegi untuk menganalisis lingkungan eksternal untuk berbagai peluang dan ancaman. Matriks IE ini berguna untuk membantu dalam memonitor isu strategis. Isu strategis yang muncul akan memengaruhi 
bagaimana kondisi Wheels and Brakes Café Surabaya di masa yang akan datang.

\section{HASIL DAN PEMBAHASAN}

Konsep desain yang ada pada Kafe ini juga memilih Pad Dock Formula Satu karena hobi dari Pemilik Kafe. Pemilik memiliki hobi otomotif sejak SD dan semua kegiatan usaha Pemilik Kafe ada di bidang otomotif. Salah satu contohnya ialah Auto Point yang mendukung operasional Auto Bucks untuk Detailing pada mobil. Pada akhirnya 3 tempat ini saling mendukung dan berhubungan. Kalau dengan konsep Auto Bucks hanya disediakan cookies, candies, dan minuman (kopi dan teh), tetapi dengan adanya Kafe ini pelanggan dapat memesan makanan berat juga.

Sejauh ini, produk unggulan Wheels and Breaks Café Surabaya ialah kopi. Tetapi,
Pemilik Kafe dan Manajer tidak ingin terlalu fokus ke menu kopi. Alasannya sederhana karena tidak ingin condong ke konsep coffee shop. Produk- produk inovasi baru pun dimunculkan untuk memberikan pilihan-pilihan lain pada konsumen (Tandjung, 2016). Produkproduk baru dimunculkan pada akhir tahun 2017 misal Mojito dan Choco Oreo yang benar-benar jadi favorit konsumen saat itu.

\section{a. Analisis Matriks SWOT (Strengths, Weaknesses, Opportunities, Threats)}

Dari hasil penelitian melalui wawancara mendalam dan dokumentasi, dapat diketahui kekuatan dan kelemahan perusahaan serta ancaman dan peluang yang saat ini (Raharjo, 2017) dihadapi oleh Wheels and Brakes Café Surabaya ialah sebagai berikut:

Tabel 1. Analisis Matriks SWOT (Strengths, Weaknesses, Opportunities, Threat)

\begin{tabular}{|c|c|c|}
\hline Faktor Eksternal & $\begin{array}{ll}\text { Kekuatan (S) } \\
\text { 1. } & \begin{array}{l}\text { Terdapat menu andalan } \\
\text { dengan tata hidang yang } \\
\text { menarik }\end{array} \\
\text { 2. } & \text { Lokasi yang strategis } \\
\text { 3. } & \text { Selalu ada inovasi menu } \\
& \text { secara periodik } \\
\text { 4. } & \text { Pelatihan khusus bagi } \\
\text { 5. } & \text { Stok bahan mentah sesuai } \\
\text { 6. } & \text { kabutuhan parkir yang luas } \\
\text { 7. } & \text { Desain interior yang unik } \\
\text { 8. } & \text { Reputasi kafe yg positif di } \\
& \text { masyarakat melalui adanya } \\
& \text { sosial media }\end{array}$ & $\begin{array}{l}\text { Kelemahan (W) } \\
\text { 1. Terjadi pengurangan tenaga kerja } \\
\text { 2. Fasilitas bagi karyawan kurang } \\
\text { diperhatikan } \\
\text { 3. Memiliki pangsa pasar yang } \\
\text { sempit dan hanya terfokus pada } \\
\text { pelanggan yang pergi ke } \\
\text { Autowash. } \\
\text { 4. Desain eksterior Kafe kurang } \\
\text { mencolok dan tertertutup pohon } \\
\text { 5. Pemasukan Kafe belum } \\
\text { mencapai BEP }\end{array}$ \\
\hline $\begin{array}{ll}\text { Peluang (O) } \\
\text { 1. }\end{array} \begin{array}{l}\text { Muncul aplikasi pembayaran } \\
\text { yang beragam (OVO dan } \\
\text { Go-Pay) } \\
\text { 2. Promosi di Sosial Media } \\
\text { rutin dan gencar } \\
\text { 3. Tingginya tingkat kunjungan } \\
\text { secara group/kelompok } \\
\text { 4. Populasi anak muda di } \\
\text { daerah Surabaya Timur } \\
\text { tinggi } \\
\text { 5. Sistem bisnis yang mudah } \\
\text { implementasikan (Model }\end{array}$ & \begin{tabular}{l}
\multicolumn{1}{c}{ Strategi S-O } \\
(S8-O2,O3) Memanfaatkan \\
media sosial sebagai sarana \\
promosi \\
(S2-O3,O5) mengadakan suatu \\
acara bekerjasama dengan \\
komunitas anak muda untuk \\
memikat lebih banyak pelanggan.
\end{tabular} & $\begin{array}{l}\text { Strategi W-O } \\
\text { (W1-O4) memunculkan tenaga } \\
\text { part time dengan target pekerja } \\
\text { mahasiswa } \\
\text { (W3-O3) menekankan pasar } \\
\text { sasaran pelanggan anak muda } \\
\text { dalam meningkatkan jumlah } \\
\text { pengunjung } \\
\text { (W4-O5) mendesain interior dan } \\
\text { eksterior yang menarik dan sesuai } \\
\text { selesar anak muda }\end{array}$ \\
\hline
\end{tabular}




\begin{tabular}{|c|c|c|}
\hline Starbucks) & & \\
\hline $\begin{array}{l}\text { Ancaman (T) } \\
\text { 1. Adanya Kafe-kafe yang } \\
\text { memiliki konsep serupa dengan } \\
\text { Wheels and Brakes Café } \\
\text { 2. Persaingan dengan motif harga } \\
\text { yang semakin kuat } \\
\text { 3. Instabilitas politik menjelang } \\
\text { pemilu } \\
\text { 4. perubahan kebijakan } \\
\text { pemerintah } \\
\text { 5. Muncul kafe-kafe baru } \\
\text { 6. Daya beli konsumen Surabaya } \\
\text { untuk menu-menu di Wheels } \\
\text { and Brakes Café relatif rendah }\end{array}$ & $\begin{array}{l}\quad \text { Strategi S-T } \\
\text { (S1-T2,T6) memunculkan } \\
\text { beberapa menu baru dengan harga } \\
\text { rendah untuk memikat pelanggan } \\
\text { yang berorientasi harga. } \\
\text { (S5-T3) memunculkan menu } \\
\text { dengan konsep fermentasi } \\
\text { sehingga lebih efisien dalam } \\
\text { mengurangi bahan terbuang. } \\
\text { (S7-T5) secara periodik } \\
\text { melakukan perubahan pada desain } \\
\text { interior Kafe agar menarik bagi } \\
\text { konsumen. }\end{array}$ & \begin{tabular}{l}
\multicolumn{1}{c}{ Strategi W-T } \\
(W3-T1) melakukan studi banding \\
dengan kafe berkonsep serupa \\
untuk dapat mempelajari strategi \\
yang memikat pasar lebih luas. \\
(W3-T2) melakukan riset pasar \\
terjadwal terhadap masyarakat \\
dengan perilaku konsumtif- \\
ekonomis \\
(W4-T4) merancang desain \\
eksterior dan papan nama Kafe
\end{tabular} \\
\hline
\end{tabular}

Sumber: Peneliti (2021)

\section{b. Analisis Matriks SPACE}

Faktor-faktor internal dan eksternal Wheels and Brakes Cafe Surabaya yang terdapat pada matrik SWOT dipilih dan dikelompokkan. Diambil masing-masing 4 faktor yang mewakili poin-poin faktor FS, ES, IS, dan CA. faktor-faktor yang terpilih diberi bobot kemudian dijumlahkan.

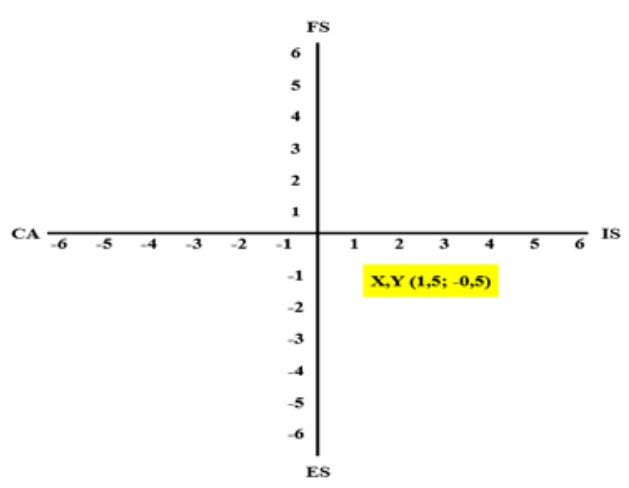

Gambar 1. Analisis Matrik SPACE
Sumber: Peneliti (2021)

Pada hasil Analisis Matriks SPACE yang mencakup Financial Strength, Industry Strength, Environmental Stability, dan Competitive Advantages didapatkan koordinat $\mathrm{x}, \mathrm{y}(1,5 ;-0,5)$ seperti gambar diatas. Posisi ini menunjukkan bahwa Wheels and Brakes Café Surabaya berada di kuadran III yaitu posisi kompetitif dengan saran strategi integrasi, penetrasi pasar, pengembangan pasar, dan pengembangan produk.

\section{c. Analisis Matrik IFAS}

Berdasarkan hasil analisis terhadap hasil wawancara dengan Manajer Wheels and Brakes Café Surabaya berkaitan dengan faktor internal di Kafe ini kemudian dicari rata-rata (mean). Adapun rata-rata pembobotan yang diberikan oleh Manajer ditunjukkan pada tabel dibawah ini:

Tabel 2. Analisis Matrik IFAS (Internal Factors Analysis Strategies)

\begin{tabular}{clccc}
\hline No. & \multicolumn{1}{c}{ Pernyataan } & Rating & Bobot & Rating x Bobot \\
\hline \multicolumn{1}{c}{ KELEBIHAN } \\
& & & \\
1 & Adanya menu andalan dengan tata hidang & 0,05 & 2 & 0,1 \\
2 & yang menarik & 0,05 & 2 & 0,1 \\
3 & Lokasi kafe yang strategis & 0,05 & 3 & 0,15 \\
4 & Selalu ada inovasi menu secara periodik & 0,01 & 1 & 0,01 \\
\hline
\end{tabular}




\begin{tabular}{|c|c|c|c|c|}
\hline 5 & Stok bahan mentah sesuai kebutuhan & 0,01 & 3 & 0,03 \\
\hline 6 & Lahan parkir yang luas & 0,1 & 2 & 0,2 \\
\hline 7 & Desain interior yang unik & 0,15 & 3 & 0,45 \\
\hline 8 & $\begin{array}{l}\text { Reputasi Kafe yang positif di masyarakat } \\
\text { melalui adanya sosial media }\end{array}$ & 0,05 & 3 & 0,15 \\
\hline \multicolumn{5}{|c|}{ KELEMAHAN } \\
\hline 1 & Pengurangan tenaga kerja & 0,03 & 1 & 0,03 \\
\hline 2 & $\begin{array}{l}\text { Fasilitas bagi karyawan kurang diperhatikan } \\
\text { Memiliki pangsa pasar yang sempit dan }\end{array}$ & 0,1 & 2 & 0,2 \\
\hline 3 & $\begin{array}{l}\text { hanya terfokus pada pelanggan yang pergi ke } \\
\text { Autopoint car wash }\end{array}$ & 0,1 & 3 & 0,3 \\
\hline 4 & $\begin{array}{l}\text { Desain eksterior Kafe kurang mencolok dan } \\
\text { tertup pohon }\end{array}$ & 0,15 & 4 & 0,6 \\
\hline \multirow[t]{2}{*}{5} & Pemasukan Kafe belum mencapai BEP & 0,15 & 4 & 0,6 \\
\hline & Total & 1 & & 2,77 \\
\hline
\end{tabular}

Sumber: Peneliti (2021)

Berdasarkan tabel 2 menunjukkan bahwa faktor yang merupakan kekuatan utama pada Wheels and Brakes Café Surabaya adalah desain interior yang unik dan berbeda dengan Kafe lainnya dengan nilai 0,45 . Sedangkan faktor yang menjadi kelemahan utama adalah desain eksterior kafe yang kurang mencolok karena tertutup pohon dan pendapatan kafe belum mencapai BEP dengan nilai 0,6. Pada tabel hasil penghitungan, total nilai faktor-faktor internal Wheels and Brakes Café Surabaya ialah sebesar 2,77.

\section{d. Analisis Matrik EFAS}

Matrik ini menggambarkan kondisi eksternal yang terdiri dari peluang dan ancaman di Wheels and Breaks Café Surabaya dengan menghitung rating dan bobotnya.

Tabel 3. Analisis Matrik EFAS (External Factors Analysis Strategies)

\begin{tabular}{|c|c|c|c|c|}
\hline No. & Pernyataan & Rating & Bobot & Rating $x$ Bobot \\
\hline \multicolumn{5}{|c|}{$\begin{array}{ll}\text { PELUANG } \\
\end{array}$} \\
\hline 1 & $\begin{array}{l}\text { Muncul aplikasi pembayaran yang beragam } \\
\text { (OVO dan Go-Pay) }\end{array}$ & 0,1 & 3 & 0,3 \\
\hline 2 & Promosi di Sosial Media rutin dan gencar & 0,1 & 4 & 0,4 \\
\hline 3 & $\begin{array}{l}\text { Tingginya tingkat kunjungan secara } \\
\text { group/kelompok }\end{array}$ & 0,1 & 4 & 0,4 \\
\hline 4 & $\begin{array}{l}\text { Populasi anak muda di daerah Surabaya Timur } \\
\text { tinggi }\end{array}$ & 0,03 & 2 & 0,06 \\
\hline 5 & $\begin{array}{l}\text { Sistem bisnis yang mudah diimplementasikan } \\
\text { (Model Starbucks) }\end{array}$ & 0,1 & 3 & 0,3 \\
\hline \multicolumn{5}{|c|}{ ANCAMAN } \\
\hline 1 & $\begin{array}{l}\text { Adanya Kafe-kafe yang memiliki konsep serupa } \\
\text { dengan Wheels and Brakes Café }\end{array}$ & 0,05 & 2 & 0,1 \\
\hline 2 & Persaingan dengan motif harga yang kuat & 0,15 & 4 & 0,6 \\
\hline 3 & Instabiliats politik menjelang pemilu & 0,15 & 3 & 0,45 \\
\hline 4 & Perubahan kebijakan Pemerintah & 0,12 & 2 & 0,24 \\
\hline 5 & Muncul kafe-kafe Baru & 0,05 & 1 & 0,05 \\
\hline 6 & $\begin{array}{l}\text { Daya beli konsumen Surabaya untuk menu-menu } \\
\text { di Wheels and Brakes Café relatif rendah }\end{array}$ & 0,05 & 3 & 0,15 \\
\hline
\end{tabular}




\section{TOTAL}

Berdasarkan tabel 3, faktor yang menjadi peluang bagi Wheels and Brakes Café Surabaya promosi di sosial media dan tingkat kunjungan Grup adalah dengan nilai sebesar 0,4. Sedangkan faktor utama yang menjadi ancaman bagi Wheels and Brakes Café Surabaya adalah persaingan dengan motif harga yang kuat dengan nilai sebesar 0,6 . Total nilai faktor-faktor eksternal kafe pada tabel diatas ialah sebesar 3,05.

\section{e. Analisis Matrik IE}

3,05

Setelah menganalisis dengan matriks IFAS dan EFAS, analisis terakhir ialah menggunakan analisis Matrik IE (InternalEksternal). Pada matriks ini skor nilai dipindahkan ke dalam Matriks IFAS dan EFAS. Nilai IFAS Wheels and Brakes Café Surabaya adalah 2,77 sedangkan skor nilai EFAS pada Wheels and Brakes Café Surabaya adalah 3,05 sehingga posisi Wheels and Brakes Café Surabaya pada masa dapat dilihat di bawah ini:

Total nilai tertimbang IFAS

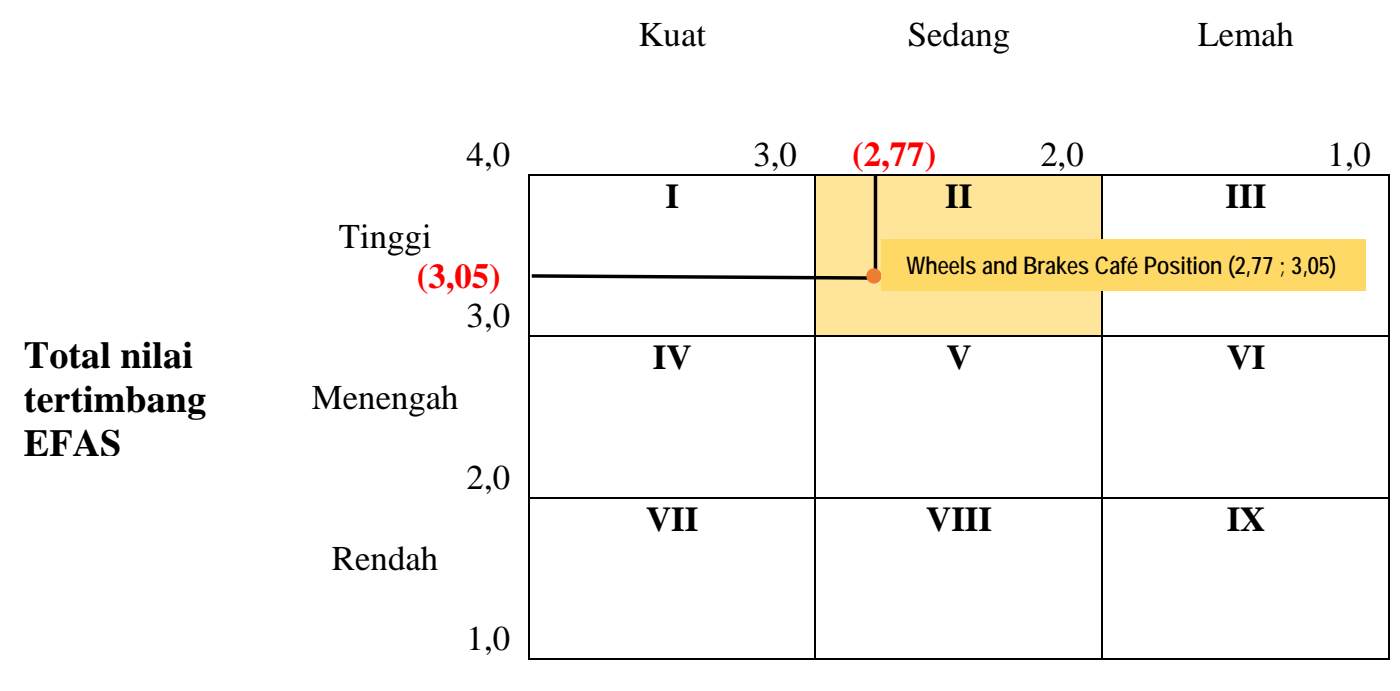

Gambar 2. Analisis Matrik IE (Internal-Eksternal)

Sumber: Peneliti (2021)

Berdasarkan matriks di atas menunjukkan bahwa Wheels and Brakes Café berada pada posisi 2 dengan saran Strategi yaitu Integrasi Horizontal. Pada prinsipnya, strategi ini menekankan pada evaluasi dan pendekatan terhadap pasar. Meskipun Wheels and Brakes Café Surabaya sedang bertumbuh, pada posisi ini masih mengindikasikan bahwa Kafe belum mampu bersaing secara efektif dan perlu mencari tahu mengapa pendekatan Kafe saat ini tidak efektif dan bagaimana Kafe dapat memperbaiki daya saingnya.

Berdasarkan hasil analisa diatas maka apabila posisi cafe dilihat dari Matrik SPACE dan Matrik IE, dimana pada Matrik SPACE posisi cafe berada pada kuadran 3 yang mengindikasikan cafe sedang dalam kondisi Kompetitif, sedangkan pada Matrik IE posisi cafe berada di sel 2 dengan kondisi bertumbuh, maka disarankan strategi integrasi horizontal sebagai startegi yang lebih tepat untuk kondisi cafe sekarang. Dimana pada strategi ini lebih mengupayakan kepemilikan atau kendali yang lebih besar terhadap pesaing perusahaan dengan berfokus pada penetrasi pasar, pengembangan pasar, dan pengembangan produk (Rahmayanti, 2015). Berdasarkan hasil wawancara dengan internal perusahaan dimana baik karyawan maupun Manajer tidak merasa terancam dengan adanya pesaing karena cafe tersebut menerapkan konsep yang berbeda.

Berdasarkan analisis matriks SWOT dapat dikatakan Wheels \& Brakes Café mempunyai kekuatan serta peluang yang besar untuk dapat 
berkembang lebih baik lagi. Berikut ini pemetaan terhadap kekuatan, Kelemahan,
Peluang, dan Ancaman utama Wheels and Brakes Café:

Tabel 4. pemetaan terhadap kekuatan, Kelemahan, Peluang, dan Ancaman

\begin{tabular}{ll}
\hline \multicolumn{1}{c}{ FAKTOR UTAMA } & \multicolumn{1}{c}{ POSISI } \\
\hline Strength (Kekuatan): & Matrik SPACE : Pertumbuhan \\
1. Desain interior yang unik & \\
Weakness (Kelemahan): & \\
1. $\quad$ Desain eksterior kafe yang kurang mencolok karena & \\
tertutup pohon & Matrik IE : Kompetitif \\
2. Pendapatan kafe belum mencapai BEP & \\
Opportunity (Peluang): & \\
1. Promosi di sosial media & \\
2. Tingginya tingkat kunjungan Group & \\
Threat (Ancaman): & \\
1. Persaingan dengan motif harga yang semakin kuat. &
\end{tabular}

Sumber: Peneliti (2021)

Berdasarkan tahapan analisa yang telah dilakukan maka strategi yang dapat diterapkan Wheels and Brakes Café, yaitu:

1. Wheels and Brakes Café harus selalu memperhatikan perkembangan pasar dalam upaya menetapkan target pasar yang akan dituju guna mengetahui yang dibutuhkan dan diinginkan konsumen, memahami gaya hidup dan perilaku konsumen, dan tingkat pendapatan. Selain itu, juga melakukan penetrasi pasar yang bertujuan keberadaan cafe dikenal dan melekat di benak konsumen pada saat mereka ingin memilih cafe yang akan dituju.

2. Mengadakan berbagai event dalam upaya mempertahankan dan menaril pelanggan baru yang disesuaikan dengan target pasar yang dilayani (seperti mengadakan event gala dinner bagi pasangan, kelompok komunitas), dan selalu melakukan inovasi terhadap makanan dan minuman yang disajikan.

3. Wheels and Brakes Café dapat melakukan strategi dengan mengkombinasikan antara kekuatan dan kelemahan dengan peluang dan ancaman, yaitu:

\section{a. Strategi S-O (Strength and Opportunity)}

1. Memanfaat media sosial sebagai sarana promosi. Dimana sejalan perkembangan tehnologi, anak muda sekarang sudah melek tehnologi dan aktif menggunakan media sosial. (S802,03).

2. Melaksanakan kerjasama dengan komunitas, seperti komunitas anak muda, komunitas arisan ibu rumah tangga, (S2-O3,O5).

\section{b. Strategi W-O (Weakness and Opportunity)}

1. Dalam upaya mengatasi kekurangan karyawan dapat dilakukan dengan menerima karyawan part time dengan menerima mahasiswa magang (W1-04).

2. Pangsa pasar lebih diperioritaskan pada anak muda dalam upaya meningkatkan jumlah pengunjung, karena anak muda lebih menyukai berkumpul dengan teman di cafe (W3-04)

3. Mendesain interior dan eksterior yang menarik dan sesuai selesar anak muda, serta menyediakan spot-spot yang menarik untuk lokasi foto (W4-O5). 
c. Strategi S-T (Strength and Threat)

1. Menyediakan berbagai macam menu baru dengan harga terjangkau bagi konsumen yang lebih berorientasi pada harga (S1-T2,T6).

2. Membuat produk baru dengan melakukan fermentasi dalam upaya menghindari adanya bahan baku yang terbuang akibatnya sepinya permintaan (S5-T3).

3. Secara berkala melakukan perubahan suasana cafe melalui penetapan tema tiap tiga bulan sekali baik pada seragam dari para karyawan maupun interior cafe yang disesuaikan dengan tema, misalnya tema cowboy, angkaan tahun 70-an, atau setiap menggunakan pakaian adat dari suatu daerah serta desain interior disesuaikan denan tema saat itu (S7-T5).

\section{d. Strategi WT (Weakness and Threat)}

1. Melakukan studi banding dengan kafe berkonsep serupa untuk mempelajari strategi yag diterapkan guna memperluas pangsa pasar (W3-T1).

2. Secara rutin melakukan tentang konsumen guna mengetahui apa yang diingikan serta mendapat gambaran tentang perilaku konsumtif dari konsumen (W3$\mathrm{T} 2)$.

3. Merancang desain eksterior dan papan nama Kafe sehingga dapat dilihat masyarakat dan akan tertarik untuk melakukan kunjungan (W4-T4).

\section{SIMPULAN DAN SARAN}

\section{Simpulan}

1. Berdasarkan hasil analisis matrik IFAS dapat dikatakan bahwa Wheels and Brakes Café memiliki posisi internal yang sedang bertumbuh, sedangkan hasil analisis matrik EFAS menunjukkan Wheels and Brakes Café Surabaya memiliki posisi eksternal yang kuat karena mampu menggunakan peluang untuk mengatasi ancaman dengan sangat baik.

2. Berdasarkan hasil matriks InternalEksternal (IE) Wheels and Brakes Café berada pada posisi bertumbuh (Strategi Integrasi Horizontal), dimana strategi yang harus dilakukan adalah melakukan pengamatan perkembangan pasar, penetrasi pasar, serta melakukan inovasi produk secara berkala.

3. Kekuatan yang dimiliki Wheels and Brakes Café dapat digunakan untuk meningkatkan jumlah pelanggan baru serta adanya dukungan dilakukan inovasi terhadap produk yang dihasilkan.

4. Berdasarkan hasil analisis matrik IFASEFAS serta matrik SWOT, maka yang menjadi kekuatan, kelemahan, ancaman, dan peluang Wheels and Brakes Café adalah:

a) Kekuatan utama Wheels and Brakes Café pada desain interior yang unik

b) Kelemahan utama Wheels and Brakes Café pada desain eksterior yang kurang mencolok serta tertutup pohon dan pendapatan belum mencapai BEP

c) Peluang utama Wheels and Brakes Café melakukan kegiatan promosi melalui sosial media serta memperhatikan target pasar pada kunjungan secara grup dan kelompok

d) Ancaman utama Wheels and Brakes Café adalah persaingan pada harga yang kuat.

5. Berdasarkan Matriks SPACE, posisi Wheels and Brakes Café pada kuadran III, dapat dikatakan pada kondisi kompetitif maka pihak Manajemen kafe sebaiknya melakukan penetrasi pasar, pengembangan pasar, serta pengembangan produk, dengan menambah tenaga penjualan, lebih mengencarkan kegiatan promosi, serta menawarkan promosi penjualan secara ekstensif.

\section{Saran}

1. Melakukan promosi secara langsung kepada pelanggan sekitar kafe, tidak hanya berfokus pada pelanggan yang mencuci mobil di Auto Car Wash seperti mengadakan acara-acara seperti 
Christmas Dinner, Lomba membuat jingle, dan Open House.

2. Mendesain eksterior Kafe yang menarik dan mudah dilihat sehingga akan menambah pelanggan-pelanggan baru, seperti menambahkan bentuk-bentuk Grafitti, lampu-lampu berwarna-warni, atau memberi taman.

3. Memperhatikan masukan dari pelanggan yang datang dan mencatat dalam Guest Review Card.

4. Dalam upaya mendukung kinerja karyawan maka perlu disediakan fasilitas ruang istirahat bagi karyawan.

\section{DAFTAR PUSTAKA}

Afandi, S. 2014. Analisis SWOT Sebagai Dasar Keputusan Strategi Pemasaran Pada Hotel Mandiri di Sidoarjo. Skripsi. Surabaya: Fakultas Ekonomi. Universitas Katolik Darma Cendika Surabaya.

Abdullah, A. 2014. Makalah: Fungsi Operasional Pemasaran Pada Perusahaan”. Jambi: Kelompok Akuntansi.

Car. 2018. Bisnis Kuliner di Surabaya Tumbuh Pesat. (m.jpnn.com/news/bisnis-kulinerdi-surabaya-tumbuh-pesat) (Diakses tgl 4 Maret 2019: Pk.12.06)

Fahmi, I. 2014. Manajemen Strategis Teori dan Aplikasi. Bandung: Alfabeta.

Fatihudin, D., Mochklas, M., \& Suryati, D.A. (2019). The Effect of Brand Image Perception and Product Quality Toward the Interest to Buy Consumer Pre-Pay IM3 Ooredoo. 1st Borobudur International Symposium on Humanities, Economics and Social Sciences (BISHESS 2019), Advances in Social Science, Education and Humanities Research, volume 436 pp. 53-57

Fred R, David. 2009. Manajemen Strategis Konsep, edisi 12. Jakarta: Salemba Empat.

Hardhiyana, Surya. 22 November 2017. “Café Dengan Suasana Paddock di Wheels and Brakes

Café

Surabaya”suryahardhiyana.com/2017/11/

22/café-dengan-suasana-paddock-diwheels-and-brakes-café-surabaya/ diunduh 14 Maret 2019 pk 12.10

Hidayatullah, N.A. 2019. Realitas Kafe Kekinian Bagi Kalangan Mahasiswa Pada Komunitas Instameet Surabaya. Jurnal Prodi Manajemen: Universitas Airlangga
Surabaya. 2017. (Jurnal.unair.ac.id) (diunduh pada 14 Maret 2019 pk 11.50).

Kotler, P. 2007. Pemasaran I. Edisi Kelima. Jakarta: Salemba Empat.

Manai, R.C. 2015. Analisis SWOT Sebagai Dasar Penetapan Strategi Pemasaran (Studi Kasus di Restoran La Rucola Surabaya). Skripsi. Surabaya: Fakultas Ekonomi. Universitas Katolik Darma Cendika Surabaya.

Mochklas, M., \& Wibowo, T.S. 2018. DasarDasar Manajemen Membangun Organisasi. Surabaya: TS. Publisher

Pearce, J.A., \& obinson. R.B. 2014. Manajemen Strategis Formulasi, Implementasi, dan Pengendalian. Jakarta: Salemba Empat.

Rahmayanti. 2015. Analisis SWOT Dalam Menentukan Strategi Pemasaran Udang Beku PT. Mustika Mina Nusa Aurora Tarakan Kalimantan Utara. Jurnal Galung Tropika. Pangkep: Politeknik Pertanian Negri Pangkep.

Raharjo, R.I. 2017. Strategi Pemasaran Melalui Analisis Strength, Weakness, Opportunity, Threath (SWOT) Pada Usaha Penyewaan Lapangan Futsal Di Scudetto Futsal Banyuwangi. Skripsi. Yogyakarta: Fakultas Ilmu Keolahragaan. Universitas Negri Yogyakarta.

Rangkuti, Freddy. 2015. Teknik Membedah Kasus Bisnis Analisis SWOT. Jakarta: PT Gramedia Pustaka Utama.

Ravikawati, C., Fatihudin, D., \& Mochklas, M. (2019). Pengaruh Harga, Citra Merek, Dan Word of Mouth Terhadap Keputusan Pembelian Di Toko Buku Gramedia Surabaya Expo. Jurnal EKSEKUTIF, 16(1): 63-79

Yadi, H. 2015. Pengetahuan Layanan Makanan Dan Minuman. Bandung: CV Alfabeta.

Sofyan, I. 2015. Manajemen Strategi Teknik Penyusunan Serta Penerapannya Untuk Pemerintah dan Usaha. Yogyakarta: Graha Ilmu.

Srinandi, Ni LP. 2016. Analisis SWOT Sebagai Dasar Menentukan Strategi Pemasaran Kompetitif (Studi Kasus: Usaha Jasa Dekorasi X). Seminar Nasional Teknologi Informasi dan Komunikasi. 2016. Bali: Jurusan Sistem Komputer Bali.

Sugiyono. 2017. Metode Penelitian Kuantitatif, Kualitatif, dan $R \& D$. Bandung: CV Alfabeta. 
Tandjung, J.W. 2016. Competitive Marketing Strategy. Jakarta: Kompas Gramedia

Ticoalu, L. K. (2013). Jurnal EMBA. Organizational Citizenship Behavior (OCB) Dan Komitmen Organisasi Pengaruhnya Terhadap Kinerja Karyawan, Vol. 1, No. 4, 782-790.
Wenda, C. O. (2015). Pengaruh Quality Of Work Life Terhadap Komitmen Organisasional Karyawan Di CV Sinar Plasindo Agora. AGORA, Vol. 3, No. 2, 483-490. 